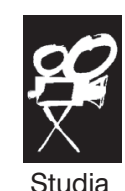

Filmoznawcze

37

Wrocław 2016

\title{
Piotr Czerkawski
}

Uniwersytet Wrocławski

\section{BLISCY NIEZNAJOMI. OBRAZ UKRAINY W POLSKIM KINIE PO 1989 ROKU}

DOI: $10.19195 / 0860-116 X .37 .11$

Polscy filmowcy niezwykle rzadko interesują się sprawami Ukrainy. Jeśli już się na to decydują, zwykle nie potrafią zrezygnować z historycznych resentymentów, protekcjonalności bądź ostentacyjnego poczucia wyższości. Pozostaje nadzieja, że na zmianę tego stanu rzeczy znacząco wpłynie głośny Wołyń Wojciecha Smarzowskiego, który opowiada o wydarzeniach stanowiących jedną z najważniejszych przyczyn nieporozumień pomiędzy naszymi narodami ${ }^{1}$.

Póki co, musimy natomiast zadowolić się pojedynczymi symptomami zwiększonego - zapewne także za sprawą sprzyjającego klimatu politycznego i zaangażowania polskich dyplomatów w sprawy Euromajdanu — zainteresowania polskich filmowców sprawą Ukrainy. Nie chodzi tu wyłącznie o twórczość Jerzego Hoffmana, która jest dla tematu istotna tak bardzo, że doczekała się w niniejszym tomie osobnego opracowania. Warto podkreślić natomiast, że na polskich festiwalach filmowych regularnie prezentowane są kolejne dzieła z dorobku najgłośniejszego obecnie twórcy legitymującego się paszportem ukraińskim — Siergieja Łoźnicy ${ }^{2}$. Więzi reżysera z naszym krajem zacieśniają się wręcz do tego stopnia, że warszawska firma Against Gravity znalazła się wśród współproducentów dwóch dokumen-

\footnotetext{
1 W okresie powstawania tekstu film Smarzowskiego wciąż pozostawał w przygotowaniu.

2 Jego twórczość doczekała się omówienia w jednym z poprzednich numerów „Studiów Filmoznawczych" (nr 35).
} 
tów z jego dorobku - Majdanu. Rewolucji godności (2014) i — pokazywanego premierowo na prestiżowym festiwalu w Wenecji - Wydarzenia (2015).

Potrzebę prezentowania filmów ukraińskich i opowiadających o Ukrainie wyraża również coraz więcej rodzimych festiwali filmowych. W programie 16. Letniej Akademii Filmowej w Zwierzyńcu w 2015 roku znalazła się — licząca 12 tytułów — sekcja „Ukraina z bliska i z oddali”. W tym samym roku „dzień ukraiński” miał miejsce także podczas 42. Ińskiego Lata Filmowego.

$\mathrm{Z}$ punktu widzenia niniejszej pracy najistotniejsze będą jednak poświęcone Ukrainie filmy stworzone przez polskich reżyserów. Zdecydowaną większość spośród nich stanowią niskobudżetowe, realizowane najczęściej na zlecenie telewizji dokumenty. Filmy te nie przedstawiają sobą większej wartości artystycznej, lecz mogą odgrywać istotną rolę edukacyjną i poznawczą. Wiele spośród nich przybliża sylwetki zapomnianych postaci, które w przeszłości działały na rzecz pojednania polsko-ukraińskiego. Inna, pokaźna grupa filmów odnosi się do rzezi wołyńskiej i jej następstw, ale o drażliwych kwestiach opowiada w tonie dalekim od oskarżycielskiego, a zamiast pogłębiać podziały, dąży do oczyszczenia i dialogu. Z satysfakcją należy odnotować zwiększającą się w ostatnich latach liczbę poruszających tematykę ukraińską filmów dokumentalnych o ambicjach artystycznych.

Dużo gorzej wygląda, niestety, sytuacja na gruncie kina fabularnego. Wątki ukraińskie pojawiają się zwykle wyłącznie na marginesach filmów wojennych bądź tych opisujących realia współczesne. Na domiar złego bohaterowie narodowości ukraińskiej zwykle traktowani są w nich z niechęcią, rezerwuje się dla nich kategorie czarnych charakterów bądź ludzi słabych, godnych pogardy, ośmieszenia czy - w najlepszym razie - pobłażliwego współczucia.

Demonstrowana, nawet jeśli mimowolnie, przez polskich reżyserów wyższość wobec ukraińskich sąsiadów pozostaje obarczona wstydliwym piętnem perspektywy neokolonialnej. Wypada żałować, że nie znalazł się jeszcze dotychczas twórca, który zdecydowałby się ją otwarcie i stanowczo skrytykować. Pewne pocieszenie stanowi fakt, że takie działania zostały podjęte już na innych polach — nauki i literatury. W tym pierwszym przypadku mowa o - opublikowanym pierwotnie na łamach „Nowej Krytyki” w 2011 roku — artykule Bogusława Bakuły — Polska kolonialna przeszłość dzisiaj. W drugim — o głośnej książce Ziemowita Szczerka Przyjdzie Mordor i nas zje, czyli tajna historia Stowian. Brawurowo napisana, łącząca autentyzm i konfabulację, utrzymana w stylu reportażu ,gonzo" publikacja dosadnie piętnuje pełne uprzedzeń spojrzenie części Polaków na Ukrainę. Trudno odmówić gorzkiej racji autorowi, gdy wkłada w usta ukraińskiej bohaterki słowa skierowane pod adresem polskiego turysty:

To ja ci powiem, dlaczego tu przyjeżdżacie — przyjeżdżacie tutaj, bo w innych krajach się z was śmieją. I mają was za to, za co wy macie nas: za zacofane zadupie, z którego się można ponabijać. I wobec którego można poczuć wyższość ${ }^{3}$.

3 Z. Szczerek, Przyjdzie Mordor i nas zje, czyli tajna historia Stowian, Kraków 2013, s. 37. Studia Filmoznawcze 37, 2016

(C) for this edition by CNS 
Czy tego chcemy, czy nie, obraz Ukrainy widziany oczyma przepełnionych wyższością kulturową bohaterów Szczerka to wizja typowa dla sporej części polskiego społeczeństwa. Nic dziwnego, że reprodukuje ją także kino. W reakcji na tę sytuację warto - w ślad za autorem Mordoru — zwalczać krzywdzące stereotypy, a także propagować filmy, które wychodzą im na przekór i przedstawiają ukraińską rzeczywistość w sposób uczciwy i dojrzały. Nie będzie przesadą stwierdzenie, że właśnie te dwa cele w głównej mierze przyświecają niniejszemu artykułowi.

\section{PRZEŁAMYWANIE BARIER}

Do reżyserów najbardziej żywo zainteresowanych tematyką ukraińską należy z pewnością lubelski dokumentalista, a także pomysłodawca i wieloletni dyrektor festiwalu „Rozstaje Europy”, Grzegorz Linkowski. Zrealizowane przez niego filmy promują postawę wyzbytą etnocentryzmu, podkreślającą wielokulturowość Ukrainy i doceniającą wysiłek osób, dzięki którym na jej ziemiach przez wiele lat żyły obok siebie osoby różnych narodowości i religii.

W dorobku Linkowskiego znajduje się między innymi zrealizowany w 1998 roku film Bardzo przyjemne miasto, próbujący przybliżyć widzom fenomen Lwowa. Miejsce to pozostaje w polskiej kulturze silnie zmitologizowane i traktowane jest niekiedy z niezamierzenie karykaturalną nostalgią, która kryje w sobie podskórną wrogość wobec jego obecnych gospodarzy. Tego rodzaju praktyki wykpił niezawodny Szczerek, który pisał w Mordorze:

Po rynku dreptali starsi Polacy: lokalni i przyjezdni. Można było od razu rozróżnić, kto jest kim. Ci przyjezdni łazili powoli, z namaszczeniem, nieco natchnionym krokiem i półgłosem narzekali. Głośno chyba jednak się bali. Mieli pretensje, że rozjebane, że zniszczone, że UPA, że Bandera. Jęczeli, że Jałta i Stalin. Mendzili, że Szczepcio i Tońcio ${ }^{4}$.

Na szczęście, w kontrze do — zapewne wciąż popularnej wśród wielu Polaków, opisanej przez Szczerka — wizji ostatnimi czasy powstają w polskiej kulturze znacznie bardziej złożone obrazy Lwowa. Jeden z nich stanowi napisany przez Żannę Słoniowską, ukraińską autorkę, zamieszkałą w Krakowie i tworzącą w języku polskim, Dom z witrażem. Miasto stanowi w tej książce nie tylko tło dla płomiennego romansu dwójki kochanków, lecz ze swoimi pięknymi zabytkami i pogmatwaną historią urasta do rangi istotnego bohatera opowieści. Słoniowska zrobiła też wiele, by udowodnić, że równie atrakcyjna i bogata w wydarzenia co przeszłość jest także współczesna codzienność Lwowa i Ukrainy. Dość powiedzieć, że zdecydowała się nawet na dopisanie do powieści epilogu, którego akcja toczy się już w czasach ogarniających kraj protestów przeciwko reżimowi Janukowycza.

Co najmniej równie interesującą wizję Lwowa odnajdziemy we wspomnianym filmie Linkowskiego. Reżyser, w towarzystwie kilkorga swych rozmówców, za-

4 Ibidem, s. 12.

Studia Filmoznawcze 37, 2016

(C) for this edition by CNS 
chwyca się zabytkami, ale nie unika również odwiedzin w mniej reprezentacyjnych zakątkach miasta. Choć dostrzega istniejące w nim po dziś dzień ślady polskości, większą wagę przywiązuje do opowieści o dawnych czasach, w których w mieście zgodnie żyli obok siebie Ukraińcy, Polacy, Żydzi, Niemcy, Węgrzy, Ormianie i Rosjanie. Zgodnie z wizją Linkowskiego, ścieranie się tak różnych kultur doprowadziło do wytworzenia się we Lwowie swoistego mikrokosmosu, w którym wykształciła się osobna mentalność i nietypowy system wartości. Zarówno w samym filmie, jak i w towarzyszących mu wywiadach reżyser lubi na przykład podkreślać, że podczas I wojny światowej lwowskie gazety więcej miejsca niż doniesieniom $\mathrm{z}$ frontu poświęcały wieściom o paraliżującym miejskie życie braku kawy. Łatwo zorientować się, że tego rodzaju cudowna, anegdotyczna gawęda również prowadzi do mitologizacji Lwowa, tyle tylko że czyni w sposób pozbawiony charakteryzujących niektóre polskie narracje odchyleń nacjonalistycznych. Prawdopodobnie właśnie to wystarczyło, by pozornie bezpieczny, nieszkodliwy film wywołał swego czasu spore kontrowersje. W jednym z wywiadów ironicznie odniósł się do nich sam Linkowski:

Wcześniej zrobiłem Bardzo przyjemne miasto — film o Lwowie, po którym zaatakowało mnie Stowarzyszenie Przyjaciół Lwowa „Semper Fidelis”. Stwierdzili, że film został zrobiony na zamówienie służb specjalnych Ukrainy, śmieszna zupełnie historia. Nie mieściło im się w głowach miasto Lwów, które do XVII wieku miało tylko i wyłącznie liturgię w języku niemieckim, miasto, w którym miastotwórczym elementem byli również Żydzi i bardzo znani Ukraińcy. Rolą dokumentalisty jest uderzanie w mity, w stereotypy. A w ogóle co to za stwierdzenie „semper fidelis" — komu wierni? Zawsze wierni czemu? Chyba takiej mitycznej postaci polskości, jaką chce nam narzucać jakiś megapedagog, który wyciągnął ją z Sienkiewiczowskiej lektury ${ }^{5}$.

Kłopoty reżysera wydają się godne wspomnienia o tyle, że bardzo wiele spośród dokumentów zrywających z czarno-białą wizją historii prowokuje gwałtowne reakcje skrajnie prawicowej części organizacji polonijnych i kresowych. Tego rodzaju działania wpływają negatywnie na relacje polsko-ukraińskie i obniżają poziom merytorycznej debaty o wspólnej przeszłości.

Sam Linkowski udowodnił jednak, że nie boi się kontrowersji. W 2009 roku zrealizował film Niewygodny poświęcony, wzbudzającej do dziś skrajne emocje, postaci greckokatolickiego arcybiskupa Andrzeja Szeptyckiego. Wątpliwości wokół tej postaci po dziś dzień budzi epizod związany z poparciem udzielonym przez duchownego Adolfowi Hitlerowi. Szeptycki miał na przykład wysłać Führerowi list gratulacyjny z okazji zdobycia przez Wehrmacht Kijowa. Metropolita później przyznał się jednak do błędu, a początkową sympatię wobec nazistów tłumaczył błędną kalkulacją polityczną i szukaniem poparcia dla idei utworzenia ukraińskiej państwowości, którą głosił jeszcze w czasach przedwojennych. Przede wszystkim

5 Rozmowa z Grzegorzem Linkowskim, http://www.umcs.pl/pl/rozmowa-z-grzegorzem-linkowskim,6052.htm (dostęp: 1 października 2015). 
jednak Szeptycki zapisał się w historii ze względu na ogrom pomocy, której udzielił ukrywającym się przed Holokaustem Żydom.

Choć Linkowski stylizuje Niewygodnego na kryminał i stara się uchwycić niejednoznaczność postaci Szeptyckiego, można zorientować się, że darzy swego bohatera sympatią. W swoim filmie zwraca uwagę na nienaturalnie długi czas trwania zarówno procesu beatyfikacyjnego hierarchy, jak i procedury przyznania mu medalu Sprawiedliwego wśród Narodów Świata. Przede wszystkim jednak podkreśla złożoność biografii swojego bohatera, który w jednostkowym życiorysie skupia dylematy całej rzeszy swoich rodaków szukających w czasie wojny okazji do uzyskania niepodległości, a także mających w sobie empatię i wrażliwość na krzywdę drugiego człowieka.

Przyjacielem Szeptyckiego, lecz również osobą pozbawioną podobnych biograficznych dwuznaczności, był ksiądz Emilian Kowcz — bohater innego filmu Linkowskiego - Proboszcz Majdanka. Katolicki duchowny działający na terenie Ukrainy zainteresował reżysera, gdyż wcielał w życie bliskie mu idee ekumenizmu. W trakcie wieloletniej posługi doprowadził do zbliżenia prawosławia, katolicyzmu i judaizmu. Swoją misję kontynuował nawet, gdy został więźniem obozu koncentracyjnego w Majdanku. Choć wiele osób proponowało mu pomoc w wydostaniu się z obozu, Kowcz konsekwentnie odmawiał. W cytowanym w filmie liście pisał:

Nie mogę stąd odejść, bo jestem tu potrzebny. Ci nieszczęśliwi ludzie, których są tu tysiące, potrzebują mnie. Jestem ich jedyną pociechą. Zostać tu jest moim obowiązkiem. Wszyscy jesteśmy tu równi: Polacy, Żydzi, Ukraińcy, Rosjanie, Litwini czy Estończycy. Jestem tu teraz jedynym kapłanem, nie mogę sobie wyobrazić, co oni by beze mnie zrobili. Tutaj widzę Boga, który jest jeden dla nas wszystkich bez względu na nasze religijne odmienności ${ }^{6}$.

Przypominanie życiorysu Kowcza i innych postaci jego pokroju stanowi najlepszą metodę do osiągnięcia przyświecającego Linkowskiemu celu, a mianowicie budowania mostów pomiędzy Polakami a Ukraińcami.

Filmy biograficzne osób zasłużonych dla relacji polsko-ukraińskich oraz mało znane wydarzenia ze wspólnej historii obu krajów stanowią domenę Mirosława Chojeckiego. Wśród dokumentów zrealizowanych przy udziale tego producenta i zasłużonego działacza Komitetu Obrony Robotników znajduje się między innymi Trudne braterstwo z 1998 roku. Film w reżyserii Jerzego Lubacha opowiada o szczegółach sojuszu zawartego w 1920 roku pomiędzy Józefem Piłsudskim a ukraińskim atamanem Semenem Petlurą. Na mocy owych ustaleń oba narody wystąpiły ramię w ramię przeciw bolszewickiej Rosji i wspólnie powstrzymały ekspansję komunizmu. Na szczególną uwagę zasługuje fakt, że pomysłodawcą powstania filmu był sam Jerzy Giedroyc, który wielokrotnie przejawiał szczerą troskę o dobro Ukrainy. Widoczne w Trudnym braterstwie wsparcie wielkiego autorytetu

${ }^{6}$ U. Buglewicz, Proboszcz Majdanka, „Tygodnik Katolicki Niedziela”, http://www.niedziela.pl/ artykul/81714/nd/zdjecia (dostęp: 1 października 2015). 
to zresztą jedna z najskuteczniejszych metod pozwalających na zwalczanie wzajemnych uprzedzeń ${ }^{7}$.

$\mathrm{Z}$ dokumentów zrealizowanych przez Chojeckiego na uwagę zasługuje z pewnością także Zaufany Piłsudskiego z 2014 roku — kolejny film o nietuzinkowej jednostce, której dziedzictwo może być dziś pomocne w zbliżaniu do siebie kultury polskiej i ukraińskiej. Bohaterem dokumentu Jolanty Kessler-Chojeckiej jest Henryk Józewski - polityk, który godził działania na rzecz niepodległości Ukrainy z bezwzględną lojalnością wobec Marszałka. Na przełomie lat 20. i 30. tytułowy bohater Zaufanego pełnił funkcję wojewody wołyńskiego. Co ciekawe, uważał, że to właśnie ten region powinien stać się przestrzenią porozumienia pomiędzy Ukraińcami a Polakami, dbał o rozwój ukraińskiej autonomii, lecz jednocześnie powściągał zapędy tamtejszych organizacji nacjonalistycznych.

\section{ZABLIŹNIANIE RAN}

W obliczu fiaska polityki Józewskiego Wołyń stał się w 1943 roku przestrzenią krwawej rzezi, której następstwa do dziś kładą się cieniem na stosunkach polsko-ukraińskich. Nad przyczynami tego stanu rzeczy w jednym z rozdziałów swojej książki Barszcz ukraiński zastanawia się kijowski korespondent Polskiego Radia, Piotr Pogorzelski. Autor pisze między innymi:

Przez wiele lat o Wołyniu na Ukrainie nie mówiono niemal nic. W czasach ZSRR był to temat tabu. Teraz, podobnie jak inne tematy historyczne, został on zepchnięty do specjalistycznego getta, skąd czasem jest wyciągany przez różnej maści polityków $(\ldots)^{8}$.

Na poprawę stanu świadomości w kwestii rzezi wołyńskiej może wpłynąć bardzo duża ilość poświęconych sprawie polskich filmów dokumentalnych, które bywają prezentowane również na Ukrainie. Do najciekawszych spośród nich należą te tytuły, które stronią od jednoznacznej wizji historii i — choć nie usprawiedliwiają Ukraińców — próbują naświetlić kontekst, w jakim dopuścili się swoich bestialskich czynów. W postawie potomków ofiar wołyńskiego ludobójstwa dopatrują się natomiast gotowości do wybaczenia.

Do takich właśnie filmów należy zrealizowane w 2013 roku Wybaczyć wszelkie zło w reżyserii wspomnianego już Grzegorza Linkowskiego. Polski dokumentalista odsłania mało znane fakty dotyczące zawartych w 1945 roku porozumień pomiędzy Armią Krajową a UPA. Na mocy tamtych ustaleń zaprzestano bratobójczych walk na Wołyniu i zdecydowano się sprzymierzyć przeciwko sowieckiemu okupantowi.

7 W serialu Jerzego Hoffmana 1920 Bitwa warszawska (2011) jest piękny portret sotnika Kryszkina (granego przez Aleksandra Domogarowa), jednego z dowódców oddziałów Petlury, oraz jest też sugestywne ukazanie dobrych, przyjaznych relacji między wojakami ukraińskimi i polskimi.

8 P. Pogorzelski, Barszcz ukraiński, Gliwice 2014, s. 231. 
Linkowski wcielił w życie brawurowy pomysł, by zamiast rozdrapywać dawne rany, skupić się na przesłankach, które spowodowały zakończenie konfliktu. Choć wówczas decydował o tym głównie polityczny pragmatyzm, opisane w Wybaczyć wszelkie zło okoliczności stanowią doskonały punkt wyjścia do rozmów o pojednaniu i wspólnym egzorcyzmowaniu demonów przeszłości. Charakteryzujące reżysera przekonanie, że dialog o polsko-ukraińskiej przeszłości jest możliwy, znalazło swoje odzwierciedlenie w strukturze filmu. Do udziału w Wybaczyć wszelkie zło Linkowski zaprosił bowiem reprezentujących obie narodowości historyków, których narracja przeplata się i tworzy skomplikowaną, kompleksową całość. O tym, że - jak w przypadku wielu dokumentów reżysera - nad opowieścią unosi się chrześcijański duch przebaczenia, świadczą końcowe fragmenty filmu. Linkowski pokazuje w nich udającą się na Wołyń polską pielgrzymkę, której patronem pozostaje ksiądz Jerzy Popiełuszko. Pełna zadumy, skromności i pokory atmosfera ostatnich scen pozwala wierzyć, że towarzyszące duchownemu hasło „Zło dobrem zwyciężaj” w niedalekiej przyszłości zyska na Wołyniu szansę praktycznej realizacji.

Wiarę tę zdaje się podzielać również Wanda Kościa, zamieszkała w Londynie dokumentalistka, która zrealizowała na Wołyniu film pod tytułem Mój przyjaciel wróg (2014). Polska reżyserka thumaczy genezę rzezi i nie pomija przy tym racji strony ukraińskiej. Przede wszystkim jednak podejmuje temat Polaków ocalałych z pożogi dzięki pomocy ukraińskich sąsiadów, którzy, często z narażeniem życia, ukrywali ich przed rozwścieczonymi rodakami. Kamera Kości towarzyszy potomkom ocalonych, którzy po latach przyjeżdżają na Wołyń, by spotkać się z rodzinami dobroczyńców. Choć reżyserka zdecydowała się opowiedzieć o ludziach, którzy w ekstremalnej sytuacji potrafili zachować człowieczeństwo, zdaje sobie sprawę, że opisane przez nią sytuacje należały do wyjątków. Ból ludzi, którzy doświadczyli rzezi wołyńskiej, jest zbyt duży, by można było oczekiwać od nich, aby zapomnieli o swych krzywdach. Jak mówi w jednym z wywiadów sama Kościa:

Myślę, że od tych, którzy przeżyli rzeź, te wszystkie straszne rzeczy, trudno oczekiwać wybaczenia. Janina, bohaterka filmu, opowiada, że Ukraińcy wymordowali 18 osób z jej rodziny. Przeżyła trójka dzieci, w tym ona. Mówi: naokoło nas jest pustka. Moje dzieci nie miały babć, dziadków, ciotek. Potrzeba kilku pokoleń, żeby te struktury rodzinne odbudować ${ }^{9}$.

Jednocześnie jednak reżyserka daje wyraz przekonaniu, że zgoda powinna stać się domeną następnych pokoleń. Podobnie jak Linkowski w Wybaczyć wszelkie zło, postanawia zakończyć swój film obrazem pełnym nadziei. W Moim przyjacielu wrogu z całą pewnością niesie ją widok polskich i ukraińskich dzieci wspólnie sprzątających groby ofiar rzezi.

9 W. Kościa, Robię filmy, nie uprawiam polityki, rozmowę przepr. Magdalena Rigamonti, Dziennik.pl,http://wiadomosci.dziennik.pl/historia/artykuly/492255, wanda-koscia-o-rzezi-na-wolyniu-bandera-nie-moze-byc-bohaterem.html (dostęp: 1 października 2015). 
Interesujący pomysł na oddanie skomplikowania rzezi wołyńskiej miała Agnieszka Arnold. Znana dokumentalistka zdecydowała się na realizację dyptyku, na który złożyły się filmy Oczyszczenie i Przebaczenie (oba zrealizowane w roku 2003). Pierwszy z nich prezentował opisywane wydarzenia z perspektywy polskiej, drugi - z ukraińskiej. Takie podejście do podejmowanego zagadnienia wypełnia — wyrażone w jednym z wywiadów — twórcze credo artystki:

Nie istnieje czarno-biała rzeczywistość. Żadnego wydarzenia nie daje się ocenić jednoznacznie. A to jest pułapka, w którą bardzo łatwo wpaść, gdy robi się takie filmy, jak moje. Ja mam obowiązek zrobić wszystko, by spojrzeć z każdej perspektywy. Oceniać jest łatwo, chodzi o to, by nie budzić złych emocji ${ }^{10}$.

W Oczyszczeniu Arnold towarzyszy w podróży na Wołyń znanemu kompozytorowi Krzesimirowi Dębskiemu, który w trakcie rzezi stracił wielu członków swej rodziny. Wraz ze swoim bohaterem reżyserka spotyka ostatnich świadków tamtych wydarzeń, wysłuchuje przerażających opowieści i robi wszystko, by ocalić ich tragedię od zapomnienia. Świetne przyjęcie Oczyszczenia koresponduje z kontrowersjami, które wzbudziła druga część dyptyku. Przebaczenie prezentuje punkt widzenia ukraińskich nacjonalistów i próbuje naświetlić przyczyny, z jakich sprzymierzyli się z hitlerowcami i doprowadzili do rzezi wołyńskiej. Niedługo po premierze pozbawiony znamion prowokacji zamysł Arnold, by po prostu wysłuchać racji drugiej strony konfliktu, został oprotestowany przez środowiska nacjonalistyczne, a reżyserkę postawiono przed komisją etyki TVP.

Niepotrzebna wrzawa towarzysząca dokumentowi Arnold, tak jak i kilku innym filmom o wspólnej historii dopuszczającym do głosu stronę ukraińską dowodzi nie tylko tego, że tytułowe Przebaczenie wciąż jeszcze pozostaje w sferze marzeń i niezrealizowanych planów. Przede wszystkim udowadnia również, że postawa niektórych środowisk w Polsce utrudnia debatę na temat wzajemnych relacji w tym samym stopniu, co oburzające nas głosy chwalące Stepana Banderę i rehabilitujące działania UPA. Kontrowersje te na szczęście nie powstrzymują reżyserów przed ich ważną i potrzebną pracą.

\section{W STRONĘ WSPÓŁCZESNOŚCI}

Tematyka ukraińska interesuje nie tylko dokumentalistów zajmujących się przeszłością. Coraz częściej reżyserów inspiruje też współczesna rzeczywistość naszych wschodnich sąsiadów. Nie chodzi tu zresztą wyłącznie o twórców pracujących na zlecenie telewizji, lecz także o tych, którzy kojarzeni są z kinem artystycznym.

10 M. Żmijewska, Trudna pamięć — przegląd filmów Agnieszki Arnold, „Gazeta Wyborcza. Białystok”, http://bialystok.wyborcza.pl/bialystok/1,35235,6684723,Trudna_pamiec_przeglad_filmow_Agnieszki_Arnold.html (dostęp: 1 października 2015). 
Należy do nich bez wątpienia Paweł Łoziński, który w 2002 roku zrealizował dokument Pani z Ukrainy. Niestety, film ów należy do najsłabszych i najbardziej wątpliwych etycznie tytułów w dorobku wybitnego skądinąd twórcy. W Pani z Ukrainy reżyser opowiada historię kobiety, którą zatrudnia w domu jako sprzątaczkę. Już w punkcie wyjścia zaznacza uprzywilejowanie względem bohaterki i obficie korzysta z niego w każdej kolejnej scenie filmu. Relacja pomiędzy przemawiającym zza kadru Łozińskim, a panią Łesią to modelowy układ pan-służąca, a okazywane bohaterce zainteresowanie każdorazowo pozostaje podszyte krzywdzącą ją pobłażliwością.

Taka postawa reżysera aż się prosi o krytykę z pozycji postkolonialnych, którą przeprowadziła swego czasu Dobrochna Dabert. W artykule Czy możliwe jest dzisiaj w Polsce kino kolonialne? Przypadek Pani z Ukrainy Pawła Łozińskiego badaczka pisze między innymi:

Dokument pt. Pani z Ukrainy, w odróżnieniu od wcześniejszych realizacji Łozińskiego, inaczej sprofilował relacje między bohaterem a realizatorem. W swoim filmie reżyser pozostał poza kadrem, natomiast jego głos z offu jest słyszalny na tyle wyraziście, iż punkt widzenia kamery da się utożsamić ze spojrzeniem reżysera. Niewidoczna fizyczność Łozińskiego ma w tym przypadku istotne znaczenie, bowiem film rozgrywa się w jego mieszkaniu, do którego przychodzi Łesia, by posprzątać i ugotować. Połowiczną obecnością domownika/realizatora zakłócone zostały standardowe relacje z bohaterką filmu dokumentalnego. Kamera w rękach Łozińskiego przestała być przezroczystym medium, za pomocą którego pokazuje się w sposób neutralny wydarzenia dziejące się przed jej obiektywem. Wyczuwalna obecność pana domu, który wdaje się w rozmowy z Łesią, każe dostrzec w spojrzeniu kamery nie bezosobowe, zobiektywizowane medium, ale samego Łozińskiego ${ }^{11}$.

Nawet jeśli protekcjonalny stosunek do pani Łesi pozostał niezamierzony przez reżysera — słynącego przecież raczej z okazywania bohaterom empatii i ciepła jego porażka powinna służyć za przestrogę innym polskim twórcom podejmującym problematykę ukraińską.

Podobne pułapki ominęli twórcy dwóch wysoko ocenianych dokumentów z 2014 roku - Piano i Dybuka. Rzeczy o wędrówce dusz. Pierwszy z nich, zrealizowany przez Vitę Drygas, córkę wybitnego dokumentalisty Macieja, to bodaj najdojrzalsza reakcja polskiego kina na fenomen Euromajdanu. Reżyserce udało się ukazać specyfikę antyrządowych protestów za pomocą wyjątkowo nośnej metafory. Drygas śledzi losy tytułowego pianina, które miało pełnić na kijowskim Majdanie funkcję barykady zatrzymującej kule słane pod adresem demonstrantów. Odnaleziona przez reżyserkę młoda pianistka zdecydowała się jednak ocalić instrument i wykorzystać go zgodnie z przeznaczeniem. Każdego dnia przychodziła więc na Majdan, by dodać otuchy protestującym i grać dla nich Etiudę rewolucyjną Chopina. W sugestywnej wizji Drygas sztuka okazuje się nadspodziewanie skutecznym

11 D. Dabert, Czy możliwe jest dzisiaj w Polsce kino kolonialne? Przypadek Pani z Ukrainy Pawła Łozińskiego, „Porównania” 2013, nr 13, s. 157-166. 
orężem walki z wrogiem. Niejako mimochodem reżyserka, wzorem Siergieja Łoźnicy i słynnego Majdanu. Rewolucji godności, obserwuje również proces, w którym muzyka integruje demonstrantów i pomaga im zbudować poczucie wspólnoty. Film Drygas zostawia nas także z nadzieją, że oto właśnie obserwujemy na Majdanie upragnione narodziny społeczeństwa obywatelskiego.

Piano miało swoją premierę na tegorocznym Krakowskim Festiwalu Filmowym (2015), gdzie spotkało się z entuzjastycznymi recenzjami. Filmem otwarcia tej samej imprezy, nagrodzonym później Złotym Lajkonikiem dla najlepszego filmu dokumentalnego, okazał się Dybuk. Rzecz o wędrówce dusz. Reżyser Krzysztof Kopczyński od dawna zdradzał zainteresowanie tematyką ukraińską. W jednym z wywiadów tłumaczył:

Szukałem odpowiedzi na pytanie, dokąd zmierza Ukraina. To mnie interesowało od bardzo wielu lat. Napisałem na ten temat artykuł do paryskiej „Kultury” w 1989 roku po pierwszej podróży na Ukrainę. Byłem związany z myśleniem o Ukrainie jako o miejscu, które jest bardzo ważne dla Polski, dla naszych interesów wschodnich, ale też jako o miejscu, które ma w sobie tajemnicę ${ }^{12}$.

Aby doszukać się prawdy o skomplikowanej ukraińskiej tożsamości, Kopczyński wybrał się do Humania. Miejsce to słynie z rzezi, którą w XVIII wieku zgotowali Polakom i Żydom Kozacy. Po latach Gonta i Żeleźniak, przywódcy tamtych działań uważani są przez część ukraińskich nacjonalistów za bohaterów narodowych. Humań zasłynął jednak także jako przestrzeń działań sławnego żydowskiego cadyka Nachmana. W Humaniu spoczęło ciało duchownego, który swego czasu obiecał zbawienie każdemu wyznawcy, który pomodli się, zaśpiewa i zatańczy przy jego grobie. Z tego powodu w dniu święta Rosz Haszana ukraińskie miasto staje się terenem pielgrzymki kilkudziesięciu tysięcy chasydów. Dybuk... nie jest jednak prostą opowieścią o dawnym miejscu kaźni, które przeistoczyło się w przestrzeń radości. Kopczyński podkreśla, że pielgrzymi często spotykają się z niechęcią miejscowych i mają do nich pretensje o gloryfikowanie kłopotliwych bohaterów z przeszłości. Według Ukraińców przybysze z Zachodu emanują z kolei arogancją, na którą pozwala im uprzywilejowanie ekonomiczne. Dybuk... nie przyznaje racji żadnej ze stron i skupia się na opisie ich trudnego, lecz nieuniknionego współistnienia. Przy okazji przemyca także uniwersalną prawdę o pełnej paradoksów ukraińskiej wielokulturowości. Podczas seansu filmu Kopczyńskiego trudno oprzeć się wrażeniu, że — pomimo wszelkich różnic kulturowych — chasydzka perspektywa w wielu punktach pozostaje bardzo zbieżna z naszym spojrzeniem na kraj wschodnich sąsiadów.

12 Krakowski Festiwal Filmowy: „Dybuk, czyli rzecz o wędrówce dusz” filmem otwarcia, http:// film.onet.pl/wiadomosci/krakowski-festiwal-filmowy-2015-dybuk-rzecz-o-wedrowce-dusz-filmemotwarcia/ (dostęp: 1 października 2015). 


\section{W CIENIU UPRZEDZEŃ}

W porównaniu z dokumentami, fabuły podejmujące wątek ukraiński rozczarowują swoją rzadkością. Jeśli już jakiś film zajmuje się kwestią naszych wschodnich sąsiadów, zazwyczaj czyni to na marginesie, przez pryzmat pojedynczych bohaterów bądź niewiele znaczących epizodów. Jeszcze bardziej rozczarowująca okazuje się tendencja większości twórców do reprodukowania stereotypów i posługiwania się myślowymi kliszami. Dość powiedzieć, że bodaj jedynym filmem, w którym doszukamy się sprzeciwu wobec protekcjonalnego traktowania Ukraińców, okazała się marna komedia Jak się pozbyć cellulitu (2011). W jednej ze scen filmu Andrzeja Saramonowicza bogata para sprzecza się o zatrudnioną niedawno ukraińską gosposię. Reżyser wykpiwa pełną uprzedzeń postawę mężczyzny, który uzasadnia swoją niechęć absurdalnymi zaszłościami historycznymi. Kompromitująca bohatera scena wpisuje się w ogólną wymowę filmu stanowiącego komediowe wezwanie do emancypacji kobiet w patriarchalnym społeczeństwie.

Postawa Saramonowicza stanowi jednak wyjątek potwierdzający niechlubną regułę. Jeszcze bardziej smutna wydaje się świadomość, że negatywny obraz Ukraińców pojawia się nie tylko w filmach reżyserów początkujących, lecz także u twórców uznawanych za mistrzów polskiego kina.

Jak można było się tego spodziewać, wątki ukraińskie bywają od czasu do czasu obecne w filmach wojennych. Jednym z epizodycznych bohaterów filmu Byt sobie dzieciak (2013) Leszka Wosiewicza jest ukraiński żołnierz Jowa. Ekranowy wizerunek bohatera jest jednoznacznie negatywny. Mężczyzna należy do słynącego z okrucieństwa i rekrutującego pospolitych przestępców oddziału SS stworzonego przez Oskara Dirlewangera. Negatywny wizerunek Jowy pogłębia fakt, że jako jedyny spośród przedstawionych w filmie dirlewangerowców nie jest rodowitym Niemcem.

Większą ambiwalencję można dostrzec w nominowanym do Oscara $W$ ciemności (2011) Agnieszki Holland, którego akcja toczy się w okupowanym Lwowie. Czarnym charakterem w filmie jest Ukrainiec Bortnik biorący udział w procesie likwidacji miejskiego getta. Mężczyzna jest zafascynowany Niemcami i namawia głównego bohatera, Leopolda Sochę, do wyłapania ukrywających się w kanałach Żydów. Na drugim biegunie sytuuje się sympatyczny Kowalew pomagający jednemu z bohaterów dostać się do lwowskiego obozu koncentracyjnego, w którym znajduje się jego żona. Fabularne znaczenie postaci Bortnika i Kowalewa, a także czas ich obecności na ekranie pozostają jednak rażąco niewspółmierne. Pytana o te kwestie Holland przekonywała w jednym z wywiadów: „Nie chodziło mi o oskarżenie któregokolwiek narodu, ale o pokazanie skomplikowanej sytuacji narodowościowej w konkretnym miejscu i czasie"13. Nie wystarczyło to jednak reżyserce, by

13 A. Holland, Agnieszka Holland o filmie W ciemności, rozmowę przepr. D. Nowicka, „Nowa Trybuna Opolska", http://www.nto.pl/magazyn/wywiady/art/4476127, agnieszka-holland-o-filmie-w-ciemnosci,id,t.html (dostęp: 1 października 2015). 
uniknąć krytyki za tworzenie negatywnego obrazu Ukraińców, która — co ciekawe — spadła na nią również ze strony polskiej prawicy ${ }^{14}$.

Większe wątpliwości niż dzieło Holland może budzić kilka filmów osadzonych w realiach współczesnej Polski. Mowa na przykład o Futrze (2007) Tomasza Drozdowicza, w którym pojawia się postać ukraińskiej służącej Oleńki. Reżyser nie zadbał o realizm szczegółów i zamiast aktorki zza wschodniej granicy zatrudnił do tej roli gwiazdę polskiego kina, Romę Gąsiorowską. W jej interpretacji Oleńka jest poczciwą, zahukaną dziewczyną, której funkcja ogranicza się do wyrażania pensjonarskiego zdziwienia ekstrawagancjami pracodawców. Największe świadectwo protekcjonalności, z jakim reżyser traktuje swoją bohaterkę, stanowi scena, w której Oleńka zamiast, zaśpiewać jakąś ukraińską pieśń ludową, intonuje rdzennie polską piosenkę „Hej, sokoły!”.

Od stereotypów nie udało się uciec nawet samemu Krzysztofowi Zanussiemu, który w zrealizowanym w 2009 roku Sercu na dtoni powierzył jedną z głównych ról słynnemu aktorowi Bohdanowi Stupce. Przed premierą reżyser nie krył ekscytacji i komplementował swego współpracownika słowami:

Jest to wielka postać, czołowy aktor Ukrainy. To ktoś — w ukraińsko- i rosyjskojęzycznym obszarze - klasy naszego Zapasiewicza, Łomnickiego czy Holoubka. Jego udział sam w sobie jest już bardzo interesujący ${ }^{15}$.

Niestety, Zanussi nie zaoferował Stupce roli na miarę jego talentu. Grany przez ukraińskiego aktora Konstanty to postać rodem z kiepskiej farsy, rysowana nazbyt grubą kreską karykatura wschodnioeuropejskiego oligarchy.

Serce na dłoni i Futro to jedne z filmów, po których doskonale rozumiemy wzburzenie Ziemowita Szczerka widoczne w Przyjdzie Mordor i nas zje. Autor kończy swą książkę emocjonalnym opisem pewnego zdarzenia z ukraińsko-polskiej granicy:

W polskim przejściu wszedłem do bramki dla obywateli UE. Patrzyłem, jak pogranicznicy w bramce obok, w bramce dla gorszych, dla unternarodów, upokarzają jakiegoś starszego Ukraińca. Był siwy i wysoki, miał elegancko przystrzyżoną bródkę. Mówił, że jest pisarzem i że ma w Krakowie spotkanie autorskie. Mówił to zresztą nienaganną polszczyzną. Polscy pogranicznicy, dwudziestokilkuletnie szczyle, mówili do niego per „ty” i pytali, dlaczego nie jedzie promować swojej książki do Kijowa. Zaciskałem pięści i było mi wstyd. Tak bardzo, kurwa, wstyd ${ }^{16}$.

${ }^{14}$ Zob. K. Wilczyński, A jednak W ciemności czarno-białe, „Pressje. Teki Klubu Jagiellońskiego", http://pressje.salon24.pl/385992,a-jednak-w-ciemnosci-czarno-biale (dostęp: 1 października 2015).

15 Materiały prasowe dystrybutora filmu MonolithFilms, http://www.audiowizualni.pl/index. php/aktualnosci/polecane-wywiady/wywiady-spis-alfabetyczny/511-krzysztof-zanussi-wywiad-ofilmie-serce-na-dloni (dostęp: 1 października 2015).

16 Z. Szczerek, op. cit., s. 221. 
Niniejszy artykuł wypada zakończyć wyrażeniem nadziei, że polscy filmowcy coraz rzadziej będą dostarczać nam pretekstu do takich odczuć. Aby to osiągnąć, wystarczy po prostu porzucić ścieżkę stereotypów i poruszać się po Ukrainie szlakami wytyczonymi przez takich twórców, jak Vita Drygas, Krzysztof Kopczyński czy Grzegorz Linkowski.

\title{
CLOSE STRANGERS. THE IMAGE OF UKRAINE IN POLISH CINEMA AFTER 1989
}

\begin{abstract}
Summary
This text happens to be an attempt to look at the image of Ukraine in Polish cinema after the political and social changes of 1989. The big part of the article focuses on TV documentaries which come back to the most significant moments of common Polish-Ukrainian history and tell us stories of people who were equally important for both cultures. The text deals also with a difficult subject of cultural superiority, ignorance and neocolonial stereotypes reflected by some Polish films about Ukraine and Ukrainian people. On the other hand, the article also analyses well-known documentaries, such as Piano by Vita Drygas or The Dybbuk. A Tale of Wandering Souls by Krzysztof Kopczyński. The author is convinced that both films are able to combine high artistic values with an empathic view of the modern Ukrainian reality and the country's complicated past. The article ends with a conclusion that those documentaries can be treated as the role models for future Polish films about Ukraine.
\end{abstract}

Translated by Piotr Czerkawski 